\title{
Bibliometric analysis of homeopathy research during the period of 1991 to 2003
}

\author{
Wen-Ta CHIU, ${ }^{\text {a }}$ YUH-SHAN Ho ${ }^{\text {b,c }}$ \\ ${ }^{a}$ Taipei Medical University, Wan-Fang Hospital, Taipei (Taiwan) \\ ${ }^{\mathrm{b}}$ School of Public Health, Taipei Medical University, Taipei (Taiwan) \\ c Bibliometric Centre, Taipei Medical University, Wan-Fang Hospital, Taipei (Taiwan)
}

\begin{abstract}
Homeopathy has been applied to clinical use since it was first presented 200 years ago. The use of the bibilometric analysis technique for examining this topic does not exist in the literature. The objective of this study is to conduct a bibliometric analysis of all homeopathy-related publications in Science Citation Index (SCI). A systematic search was performed using the SCI for publications during the period of 1991 to 2003. Selected documents included 'Homoeopathy, Homoeopathic, Homeopathy, or Homeopathic' as a part of the title, abstract, or keywords. Analyzed parameters included authorship, patterns of international collaboration, journal, language, document type, research address, number of times cited, and reprint author's address. Citation analysis was mainly based on the impact factor as defined by the Journal Citation Reports (JCR) and on citations per publications (CPP), which is used to assess the impact relative to the entire field and is defined as the ratio between the average numbers of citations per publications in a certain period. Of total articles, $49 \%$ had a single author. The UK, the US, and Germany produced $71 \%$ of the total output, while European countries as a whole also contributed $65 \%$ of the total share of independent publications. English remains the dominant language, it comprised only $76 \%$, while German contributed $18 \%$, and the remaining where distributed among 8 European languages. More document types and languages, and fewer pages have appeared in homeopathy research. $3.5 \%$ of papers were cited more than 10 times in three years after publication, and $60 \%$ were never cited. Small-group collaboration was a popular method as co-authorship. The top 3 ranking countries of publication were the UK, the US, and Germany. The US dominated citation followed by the UK, and then Germany. In addition, a simulation model was applied to describe the relationship between the cumulative number of citations and the paper life.
\end{abstract}

\section{Introduction}

Alternative or complementary medicine is on gaining popularity the world. The basic notions of alternative medicine differ from those of current scientific medicine. Homeopathy, derived from Greek words 'homeo' (similar) and 'pathos' (suffering), is one of the often-used alternative medical systems in the world. It is based on three principles: like cures like, minimal dose, and single remedy (THE BURTON GOLDBERG

Received July 31, 2004

Address for correspondence:

YUH-SHAN HO

Bibliometric Centre, Taipei Medical University, Wan-Fang Hospital

111 Hsing-Long Road Sec. 3, Taipei 116, Taiwan

E-mail:ysho@tmu.edu.tw

$0138-9130 /$ US $\$ 20.00$

Copyright (C) 2005 Akadémiai Kiadó, Budapest

All rights reserved 
GROUP, 1993). In other words, cures are given according to similar characteristics with minimal dosages of a single substance. It was first described by Samuel Hahnemann (1755-1843) who was a physician, chemist, linguist, historian of medicine, and scientific revolutionary.

Bibliometrics is a type of research method used in library and information sciences. It utilizes quantitative analysis and statistics to describe patterns of publications within a given topic, field, institute, or country. One common way of conducting bibliometric research is to use the Social Science Citation Index (SSCI), the Science Citation Index (SCI), or the Arts and Humanities Citation Index (A\&HCI) databases to trace citations. Among medical topics, the SCI and SSCI have been used for a bibliometric analysis of the citations in Ranganathan's publications (LANCASTER et al., 1992), a Spanish investigation of international pharmacy and pharmacology journals (BORDONS et al., 1996), digestive laparoscopic surgery (TUTOSAUS et al., 2001), and oncological research overview in the European Union (UGOLINI \& MELA, 2003). Alternative medicine has been studied (WAKIJI, 1997) and some related alternative therapy topics, for instance, acupuncture (ZHANG, 1995), chiropractic (KEATING et al., 1998), herbal medicine (EVANS, 2001), Qigong (ZHANG et al., 1997), and veterinary medicine (RIVAS et al., 1997) have also been analyzed using bibliometric methods. Evaluating the performance of each research topic is necessary in order to indicate the impact and contribution of authors in their respective fields.

Our purpose was to study the homeopathy research performance based on 977 papers published in Science Citation Index (SCI)-indexed periodicals between 1991 and 2003. These documents were analyzed and evaluated according to publication and citation distribution and were used to determine the quantitative characteristics of homeopathy research.

\section{Materials and methods}

The 2002 edition of the Journal Citation Reports (JCR), published by the Institute for Scientific Information (ISI), lists 5876 journals in the Science Citation Index (SCI). Documents used in this study were based on the database of the SCI subscribed from the ISI Web of Science, Philadelphia, PA, USA. 'Homoeopathy, homoeopathic, homeopathy, and homeopathic' were used as keywords to search titles, abstracts, or keywords. Articles, biographical items, book reviews, corrections, corrections and additions, editorial materials, letters, meeting abstracts, news items, notes, and reviews were obtained from the results of the search for document types. Articles originating from England, Scotland, Northern Ireland, and Wales were grouped under the UK heading. The impact factor (IF) of a journal was determined for each document as reported in the JCR 2002. Collaboration type was determined by the address of each 
author, where 'independent' was assigned if no collaboration was presented. 'International collaboration' was assigned if the paper was cosigned by researchers from more than 1 country.

The bibliometric impact of a publication is assessed in terms of the number of citations that it has received relatively to other outputs in the journal. Let total papers be $\mathrm{P}$ and $\mathrm{C}$ be the number of total citations for the first 3 years since the papers were published. The average number of citations per publications (CPP) is defined as the total citations over total publications to produce a value for the average citation per paper produced. In some cases, we only discussed the documents published in the period from 1991 to 2000 because there were no data for CPP after 2000.

\section{Results and discussion}

Documents were analyzed according to their type, language of publication, page count, publication output, authorship, country of publication, collaboration, publication pattern, and most frequently cited paper.

\section{Type of document}

The distribution of document type identified by ISI was analyzed. From this analysis, 11 document types were found. The paper article was the most frequently used document type comprising $58 \%$ of the total production, followed by letters $(245,25 \%)$. Editorial materials $(75,7.7 \%)$, reviews $(60,6.1 \%)$, news items $(21,2.2 \%)$, notes $(15$, $1.5 \%)$, meeting abstracts $(13,1.3 \%)$, corrections $(6,0.61 \%)$, book reviews $(5,0.51 \%)$, biographical items $(1,0.10 \%)$, and corrections and additions $(1,0.10 \%)$ showed lesser significance than articles and letters. The low percentage of articles has been reported in the severe acute respiratory syndrome-related research in the beginning stage (CHIU et al., 2004). In the case of homeopathy research may be related to the low level of consolidation of the field.

\section{Language of publication}

The language in which the documents were published was dominated by English (741, 76\%) followed distantly by German (180, 18\%), French $(24,2.5 \%)$, Dutch (12, $1.2 \%$ ), Russian (7, 0.72\%), Hungarian (6, 0.61\%), Spanish (3, 0.31\%), Danish (2, $0.21 \%$ ), Czech $(1,0.10 \%)$, and Polish (1, 0.10\%). Even though English remains the dominant language, it composed only $76 \%$ while German contributed $18 \%$ and the remaining were distributed among 8 European languages. German documents were 
much more numerous than seen in other research fields because homeopathy was started in Germany, and therefore much research has been published in German and European languages.

\section{Page count}

There were 4726 pages in the total of 977 documents for an average of 4.8 pages document. Among these documents, 231 papers (24\%) were consisted of 1 page, 140 (14\%) of 2 pages, $97(9.9 \%)$ of 3 pages, $89(9.1 \%)$ of 6 pages, $84(8.6 \%)$ of 4 pages, 74 (7.6\%) of 5 pages, 64 (6.6\%) of 7 pages, 48 (4.9\%) 8 of pages, 35 (3.6\%) of 9 pages, 21 $(2.5 \%)$ of 10 pages, and $94(9.6 \%)$ for the others. Four hundred sixty-eight $(48 \%)$ documents were consisted of 1 to 3 pages. The distribution of document type shows that a high number of non-article materials such as editorials and letters which are low number of page. Therefore the average number of pages per document was lower than other fields.

\section{Publication output}

The results of publication output are shown in Table 1. For the period from 1991 to 2003, the cumulative number of publications increased. In 1991, 62 papers were published, while in 2003 the cumulative number of publications was 977. Figure 1 shows that a significant correlation between yearly cumulative number of publications and the year published was made with two linear relations having a high coefficient of determination ( $>0.992)$. The difference of the cumulative trend was significant between the two periods from 1991 to 1997 and 1997 to 2003. Linear fitting suggested that yearly publications were constantly sustained in each year. However, the slope of the fitted straight lines for the period from 1997 to 2003 was 100, which doubled that of the period from 1991 to 1997. In other words, there were annual averages of 50 publications for the early period and 100 for the later period.

\section{Authorship}

Average authors per document, from 1991 to 2003, was 2.3. Of the 977 papers, 480 (49\%) were written by a single author, $176(18 \%)$ by 2 authors, $121(12 \%)$ by 3 authors, $76(7.8 \%)$ by 4 authors, $60(6.1 \%)$ by 5 authors, $19(1.9 \%)$ by $6,16(1.6 \%)$ by 7 authors, $8(0.82 \%)$ by 8 authors, $6(0.61 \%)$ by 9 authors, and 1 each $(0.10 \%)$ by 10,12 , and 20 authors. However, there were $12(1.2 \%)$ instances with no author information in the ISI Web of Science. For this reason, not all of the 977 papers were included in some of the analyses in this study. The most-frequent number of authors was 1 to 3 , according for $777(80 \%)$ papers. 
W. T. CHIU, Y. S. Ho: Homeopathy research

Table 1. Annual publication output in homeopathy

\begin{tabular}{ccc}
\hline Year & Number of publications & Cumulative \\
\hline 1991 & 62 & 62 \\
1992 & 45 & 107 \\
1993 & 35 & 142 \\
1994 & 50 & 192 \\
1995 & 56 & 248 \\
1996 & 57 & 305 \\
1997 & 63 & 368 \\
1998 & 111 & 479 \\
1999 & 87 & 566 \\
2000 & 101 & 667 \\
2001 & 92 & 759 \\
2002 & 110 & 869 \\
2003 & 108 & 977 \\
\hline
\end{tabular}

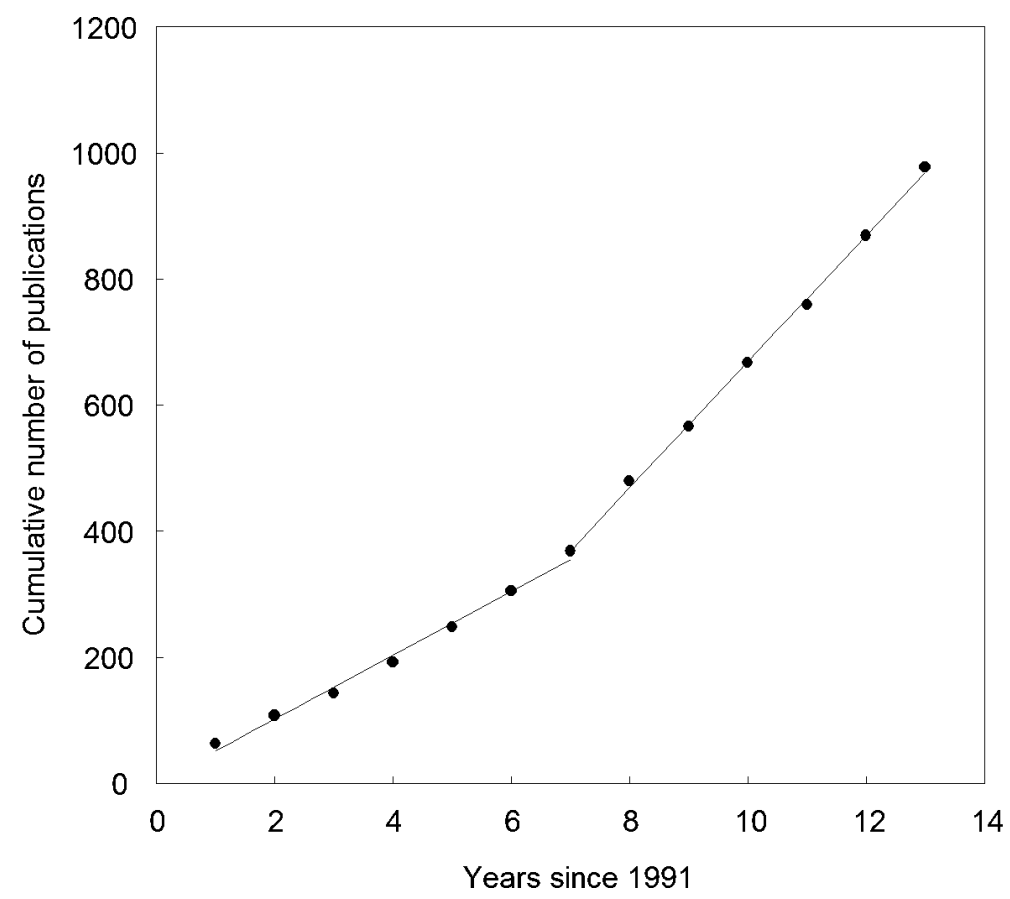

Figure 1. Cumulative number of publications by year 
W. T. CHIU, Y. S. Ho: Homeopathy research

\section{Publication patterns}

In total, 977 papers were published in 328 journals including specialty journals, but also journals of other disciplines. Out of the 328 journals, 194 (59\%) journals contained only 1 document, 53 (17\%) journals contained 2, 29 (8.8\%) journals contained 3, and 9 (2.7\%) journals contained 4 documents. Table 2 shows the most 20 published journals with the impact factor, the ISI category of journals, the position of the journal in its category, number of papers and percentage of total documents.

Table 2. The 20 most active journals with the number of papers impact factor, ISI category of journals and the position of the journal in its category

\begin{tabular}{|c|c|c|c|c|}
\hline Journal & IF & $\mathrm{P}(\%)$ & ISI category & Position \\
\hline British Medical Journal & 7.585 & $42(4.3)$ & Medicine, General \& Internal & $6 / 107$ \\
\hline $\begin{array}{l}\text { Journal of Alternative and Complementary } \\
\text { Medicine }\end{array}$ & 1.261 & $38(3.9)$ & $\begin{array}{l}\text { Integrative \& Complementary } \\
\text { Medicine }\end{array}$ & $2 / 9$ \\
\hline $\begin{array}{l}\text { Journal of the Royal Society } \\
\text { of Medicine }\end{array}$ & 0.714 & $31(3.2)$ & Medicine, General \& Internal & $57 / 107$ \\
\hline Veterinary Record & 1.221 & $31(3.2)$ & Veterinary Sciences & $23 / 129$ \\
\hline Tierarztliche Umschau & 0.289 & $26(2.7)$ & Veterinary Sciences & $87 / 129$ \\
\hline $\begin{array}{l}\text { Forschende Komplementarmedizin und } \\
\text { Klassische Naturheilkunde }\end{array}$ & 0.646 & $25(2.6)$ & $\begin{array}{l}\text { Integrative \& Complementary } \\
\text { Medicine }\end{array}$ & $7 / 9$ \\
\hline $\begin{array}{l}\text { Complementary Therapies in } \\
\text { Medicine }\end{array}$ & 1.507 & $23(2.4)$ & $\begin{array}{l}\text { Integrative \& Complementary } \\
\text { Medicine }\end{array}$ & $1 / 9$ \\
\hline Forschende Komplementarmedizin & - & $23(2.4)$ & - & - \\
\hline $\begin{array}{l}\text { Alternative Therapies in Health and } \\
\text { Medicine }\end{array}$ & 0.92 & $21(2.2)$ & $\begin{array}{l}\text { Integrative \& Complementary } \\
\text { Medicine }\end{array}$ & $5 / 9$ \\
\hline Pediatrics & 3.416 & $19(1.9)$ & Pediatrics & $2 / 68$ \\
\hline Lancet & 15.397 & $18(1.8)$ & Medicine, General \& Internal & $3 / 107$ \\
\hline Perfusion & 0.385 & $15(1.5)$ & Peripheral Vascular Disease & $49 / 52$ \\
\hline Praktische Tierarzt & 0.244 & $14(1.4)$ & Veterinary Sciences & $93 / 129$ \\
\hline $\begin{array}{l}\text { Canadian Veterinary Journal-Revue } \\
\text { Veterinaire Canadienne }\end{array}$ & 0.742 & $13(1.3)$ & Veterinary Sciences & $46 / 129$ \\
\hline Tijdschrift Voor Diergeneeskunde & 0.113 & $13(1.3)$ & Veterinary Sciences & $114 / 129$ \\
\hline $\begin{array}{l}\text { American Journal of Health-System } \\
\text { Pharmacy }\end{array}$ & 1.305 & $11(1.1)$ & Pharmacology \& Pharmacy & $109 / 188$ \\
\hline Archives of Internal Medicine & 6.749 & $11(1.1)$ & Medicine, General \& Internal & $7 / 107$ \\
\hline Indian Veterinary Journal & 0.061 & $11(1.1)$ & Veterinary Sciences & $121 / 129$ \\
\hline $\begin{array}{l}\text { Schweizerische Medizinische } \\
\text { Wochenschrift }\end{array}$ & 0.304 & $11(1.1)$ & Medicine, General \& Internal & $92 / 107$ \\
\hline Medical Hypotheses & 0.725 & $10(1.0)$ & $\begin{array}{l}\text { Medicine, Research \& } \\
\text { Experimental }\end{array}$ & $60 / 74$ \\
\hline
\end{tabular}


The British Medical Journal published the most papers (42, 4.3\%), followed by the Journal of Alternative and Complementary Medicine (38, 3.9\%), Veterinary Record (31, 3.2\%), and Journal of the Royal Society of Medicine (31, 3.2\%). The impact factor (IF) of a journal is defined by the JCR, and is derived by dividing the number of current citations to articles published in the two previous years by the total number of articles published in the two previous years. It is a measure of the frequency with which the average article in a journal has been cited in a particular year. The impact factor is used to evaluate a journal's relative importance, especially when compared to others in the same field. The distribution of papers by reference to their IF was as follows: $3.2 \%$ of total papers had an IF of $>10,6.7 \%$ had an IF of $5-10,7.1 \%$ had an IF of $3-5,28 \%$ had an IF of $1-3,48 \%$ had an IF of $<1$, and $7.3 \%$ had no information on IF. Sixty-nine percent of papers were published in journals with an IF of lower than 2. The mean impact factor of the journals was 1.63 . The journal with the highest impact factor (30.432) was Nature.

\section{Country of publication}

There were 180 (18\%) papers without author address information on the ISI Web of Science. For this reason, not all of the 977 papers were included in this analysis. Among the 797 papers with author address information, published from 1991 to 2003,58 (7.3\%) publications were international collaborations and 739 (93\%) were independent publications, but they were diverse, covering 44 different countries, with most papers originating from to the UK $(208,26 \%)$, the US $(183,23 \%)$, and Germany $(176,22 \%)$. This result is unusual, as the US is ranked top in most research fields in publications, followed distantly by other countries. Six countries had no independent and 14 countries had no collaborative publications. Seventeen countries contributed only 1 or 2 independent publications, and 20 countries contributed only 1 or 2 collaborative publications (Table 3). Figure 2 shows the relationship of cumulative percentage of publications against the number of the countries, and it indicates that 7 countries accounted for $80 \%$ of the papers on homeopathy. The geographic distribution of independent publications showed that 482 more from Europe (65\% by 21 countries), 181 were from the Americas $(25 \%, 8$ countries), 61 were from Asia $(8.3 \%, 12$ countries), 13 were from Oceania (1.8\%, 2 countries), and 2 were from Africa $(0.27 \%, 1$ country). The UK had the most independent publications at $25 \%$ of all independent publications followed by Germany and the US with $21 \%$ each. However, the US was the most frequent partner accounting for comprising $50 \%$ of the international collaborative publications followed by the UK with $43 \%$ and Germany with $36 \%$. 
W. T. CHIU, Y. S. Ho: Homeopathy research

Table 3. Publication activity of countries from 1991 to 2003

\begin{tabular}{|c|c|c|c|c|c|c|}
\hline Country & $\mathrm{P}$ & $\mathrm{P} \%$ & IP & IP\% & $\mathrm{CP}$ & $\mathrm{CP} \%$ \\
\hline UK & 208 & 26 & 183 & 25 & 25 & 43 \\
\hline USA & 183 & 23 & 154 & 21 & 29 & 50 \\
\hline Germany & 176 & 22 & 155 & 21 & 21 & 36 \\
\hline France & 39 & 4.9 & 36 & 4.9 & 3 & 5.2 \\
\hline India & 37 & 4.6 & 35 & 4.7 & 2 & 3.5 \\
\hline Switzerland & 29 & 3.6 & 27 & 3.7 & 2 & 3.5 \\
\hline Canada & 24 & 3.0 & 20 & 2.7 & 4 & 6.9 \\
\hline Netherlands & 23 & 2.9 & 19 & 2.6 & 4 & 6.9 \\
\hline Austria & 19 & 2.4 & 12 & 1.6 & 7 & 12 \\
\hline Italy & 16 & 2.0 & 15 & 2.0 & 1 & 1.7 \\
\hline Australia & 12 & 1.5 & 8 & 1.1 & 4 & 6.9 \\
\hline Israel & 12 & 1.5 & 8 & 1.1 & 4 & 6.9 \\
\hline Russia & 8 & 1.0 & 7 & 0.95 & 1 & 1.7 \\
\hline Brazil & 7 & 0.88 & 5 & 0.68 & 2 & 3.5 \\
\hline Sweden & 7 & 0.88 & 5 & 0.68 & 2 & 3.5 \\
\hline Spain & 7 & 0.88 & 7 & 0.95 & 0 & 0 \\
\hline Pakistan & 6 & 0.75 & 4 & 0.54 & 2 & 3.5 \\
\hline Belgium & 5 & 0.63 & 4 & 0.54 & 1 & 1.7 \\
\hline New Zealand & 5 & 0.63 & 5 & 0.68 & 0 & 0 \\
\hline Ukraine & 4 & 0.50 & 2 & 0.27 & 2 & 3.5 \\
\hline Denmark & 4 & 0.50 & 4 & 0.54 & 0 & 0 \\
\hline Mexico & 3 & 0.38 & 0 & 0 & 3 & 5.2 \\
\hline Greece & 3 & 0.38 & 1 & 0.14 & 2 & 3.5 \\
\hline Hungary & 3 & 0.38 & 2 & 0.27 & 1 & 1.7 \\
\hline Ireland & 3 & 0.38 & 2 & 0.27 & 1 & 1.7 \\
\hline Poland & 3 & 0.38 & 2 & 0.27 & 1 & 1.7 \\
\hline Norway & 3 & 0.38 & 3 & 0.41 & 0 & 0 \\
\hline Colombia & 2 & 0.25 & 1 & 0.14 & 1 & 1.7 \\
\hline Turkey & 2 & 0.25 & 1 & 0.14 & 1 & 1.7 \\
\hline Japan & 2 & 0.25 & 2 & 0.27 & 0 & 0 \\
\hline South Africa & 2 & 0.25 & 2 & 0.27 & 0 & 0 \\
\hline Argentina & 1 & 0.13 & 0 & 0 & 1 & 1.7 \\
\hline Bulgaria & 1 & 0.13 & 0 & 0 & 1 & 1.7 \\
\hline Chile & 1 & 0.13 & 0 & 0 & 1 & 1.7 \\
\hline Hong Kong & 1 & 0.13 & 0 & 0 & 1 & 1.7 \\
\hline Nepal & 1 & 0.13 & 0 & 0 & 1 & 1.7 \\
\hline Armenia & 1 & 0.13 & 1 & 0.14 & 0 & 0 \\
\hline Czech Republic & 1 & 0.13 & 1 & 0.14 & 0 & 0 \\
\hline Jamaica & 1 & 0.13 & 1 & 0.14 & 0 & 0 \\
\hline Romania & 1 & 0.13 & 1 & 0.14 & 0 & 0 \\
\hline Rep of Georgia & 1 & 0.13 & 1 & 0.14 & 0 & 0 \\
\hline Slovenia & 1 & 0.13 & 1 & 0.14 & 0 & 0 \\
\hline United Arab Emirates & 1 & 0.13 & 1 & 0.14 & 0 & 0 \\
\hline USSR & 1 & 0.13 & 1 & 0.14 & 0 & 0 \\
\hline
\end{tabular}

P: Total publications

IP: Single country publications

$\mathrm{CP}$ : International collaboration publications 


\section{Citation analysis}

The citation analysis is the citation count for a journal, an article, a field, or a country's publications. This is the frequency with which papers published in a journal are cited in other papers. The total citation count was obtained from SCI, Web of Science, and this shows the total number of times that a particular paper has been cited by all journals listed in the database. The number of citations does not actually indicate the quality of a paper, but is a measure of its impact or visibility. Further study was carried out by comparing the CPP in the period from 1991 to 2001; there were 1205 authors in a total of 748 publications with an average of 2.1 co-authors. Among homeopathy papers, the most frequently cited was 'Trends in alternative medicine use in the United States, 1990-1997: results of a follow-up national survey'.

This paper published by EISENBERG et al. (1998), in the JAMA-Journal of the American Medical Association (with an IF of 16.783) was cited 1172 times since it was published to 2003. Eisenberg of the Beth Israel Deaconess Medical Center, Harvard Institutes of Medicine, the US, published this most frequently cited paper not only as the first author but also as the corresponding author. The average number of citations per publications (CPP) was defined as the total citation for the first 3 years (included the published year and the followed two years) over total publications to produce a value for the average citation per paper produced. In order to analyze the CPP for authors, 748 homeopathy papers with author address information were considered, but the most frequently cited paper was excluded because it was not possible to obtain the first 3 years of citations for this paper from the ISI. It was found that 747 homeopathy papers were cited 1426 times by various journals with a frequency of from 0 to 89 times and a CPP average of 1.9 .

Twenty-six (3.5\%) of the papers were cited more than 10 times, while $7.1 \%$ (53) were cited 5 to 10 times, indicating that 446 papers or $60 \%$ were never cited. A list of the 21 most frequently cited papers (citations in three years after publication) between 1991 and 2001 was shown in Appendix A. These top 21 papers, were written by 70 authors from 5 different countries, were all published in English. Fifteen documents were articles, 2 were editorial materials, and 4 were review papers. Three documents were international collaborations. The US dominated the citation frequency by its outstanding production with 11 papers, followed by the UK with 6 papers, each the Netherlands and Germany with 3 papers, and Australia with 1 of the top 21 most frequently cited papers. Eisenberg published 3 of the 21 most frequently cited papers and is the most frequently cited author in homeopathy research in the respective orders. Among all authors, Eisenberg can be seen to be the author with most contributing in citations. Baldwin, Calabrese, Clausius, Jonas, Linde, Melchart, Ramirez, and Vandenbroucke each contributed 2 of the 21 most frequently cited papers. Sixty-one authors contributed to only 1 of the 21 most frequently cited papers (Table 4). 
W. T. CHIU, Y. S. Ho: Homeopathy research

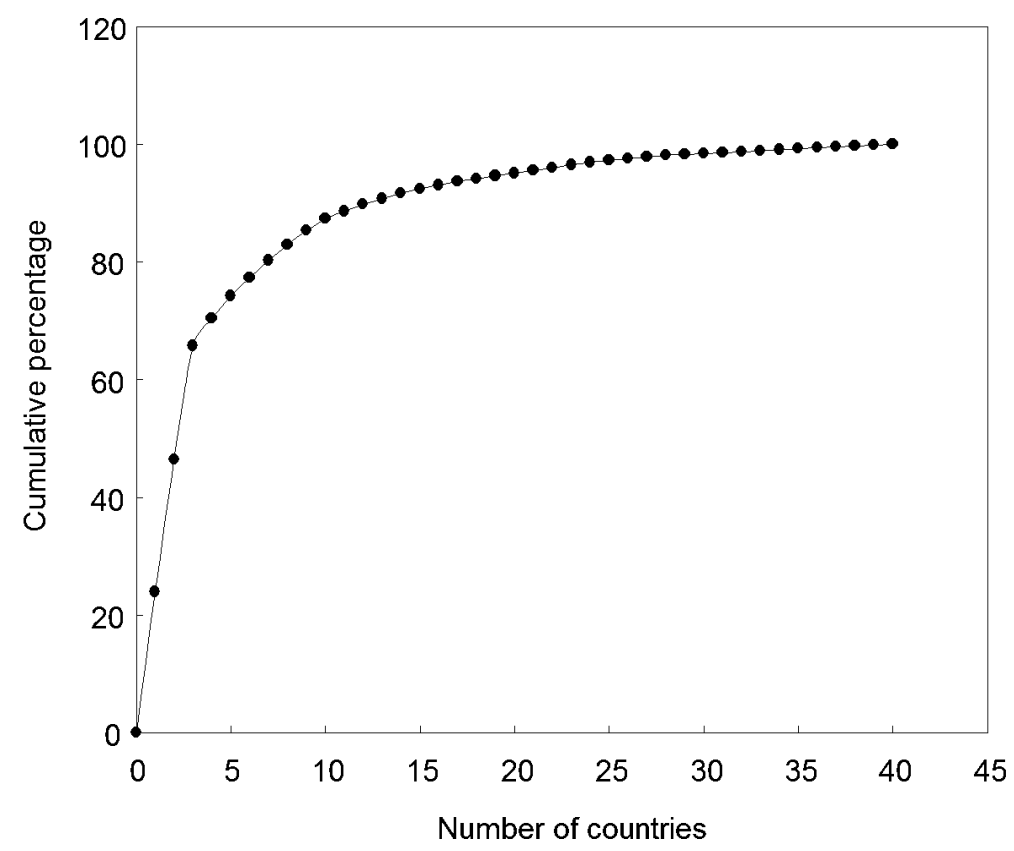

Figure 2. Cumulative percentage of homeopathy papers by countries

Table 4. Distribution of publications and citations in three years after publication by number of authors per document between 1991 and 2001

\begin{tabular}{rrrrc}
\hline No. authors & \multicolumn{1}{c}{ P } & $\%$ & \multicolumn{1}{c}{ C } & CPP \\
\hline Anon & 11 & 1.5 & 0 & 0 \\
1 & 396 & 52 & 315 & 0.80 \\
2 & 138 & 18 & 310 & 2.3 \\
3 & 85 & 11 & 302 & 3.6 \\
4 & 55 & 7.3 & 133 & 2.4 \\
5 & 38 & 5.0 & 127 & 3.3 \\
6 & 12 & 1.6 & 58 & 4.8 \\
7 & 13 & 1.7 & $1301 *$ & $100^{*}$ \\
8 & 6 & 0.79 & 21 & 3.5 \\
9 & 3 & 0.40 & 19 & 6.3 \\
10 & 1 & 0.13 & 0 & 0 \\
12 & 1 & 0.13 & 2 & 2.0 \\
\hline
\end{tabular}

*: Included the most cited paper which citation was total citation since it published to 2003 P: Total publications

$\mathrm{C}$ : Cited times for the first three years since it published

CPP: Citation per publication 
Table 5. Most cited papers for each year from 1991 to 2002

\begin{tabular}{|c|c|c|c|c|c|}
\hline No. AU & Authors & DT & Country & $\mathrm{C}$ & PY \\
\hline 3 & Kleijnen, J, Knipschild, P, Terriet, G & Review & Netherlands & 212 & 1991 \\
\hline 2 & Kleijnen, J, Knipschild, P & Article & Netherlands & 39 & 1992 \\
\hline 3 & Himmel, W, Schulte, M, Kochen, MM & Article & Germany & 51 & 1993 \\
\hline 2 & Fisher, P, Ward, A & Article & UK & 201 & 1994 \\
\hline 2 & Verhoef, TJ, Sutherland, LR & Article & Canada & 44 & 1995 \\
\hline 2 & Lewith, GT, Watkins, AD & Review & UK & 21 & 1996 \\
\hline 7 & $\begin{array}{l}\text { Linde, K, Clausius, N, Ramirez, G, Melchart, D, } \\
\text { Eitel, N, Hedges, LV, Jonas, WB }\end{array}$ & Review & USA, Germany & 241 & 1997 \\
\hline 7 & $\begin{array}{l}\text { Eisenberg, DM, Davis, RB, Ettner, SL, Appel, S, } \\
\text { Wilkey, S, van Rompay, M, Kessler, RC }\end{array}$ & Article & USA & 1172 & 1998 \\
\hline 6 & $\begin{array}{l}\text { Linde, K, Scholz, M, Ramirez, G, Clausius, N, } \\
\text { Melchart, D, Jonas, WB }\end{array}$ & Article & Germany, USA & 35 & 1999 \\
\hline 2 & Ernst, E, White, A & Article & UK & 47 & 2000 \\
\hline 3 & Thomas, KJ, Nicholl, JP, Coleman, P & Article & UK & 38 & 2001 \\
\hline 7 & $\begin{array}{l}\text { Lewith, GT, Watkins, AD, Hyland, ME, Shaw, S, } \\
\text { Broomfield, JA, Dolan, G, Holgate, ST }\end{array}$ & Article & UK & 18 & 2002 \\
\hline 2 & Linde, K, Willich, SN & Article & Germany & 6 & 2003 \\
\hline 5 & $\begin{array}{l}\text { Stevinson, C, Devaraj, VS, Fountain-Barber, A, } \\
\text { Hawkins, S, Ernst, E }\end{array}$ & Article & UK & 6 & 2003 \\
\hline 3 & MacGregor, EA, Brandes, J, Eikermann, A & Article & $\begin{array}{l}\text { UK, USA, } \\
\text { Germany }\end{array}$ & 6 & 2003 \\
\hline
\end{tabular}

No. AU: Number of authors

DT: Document type

C: Cited times since it published to 2003

PY: Publication year

In total, 759 papers were published from 1991 to 2001 by 1205 authors from 40 countries. Of these 759 papers, 457 (60\%) papers written by $1022(85 \%)$ authors were not cited in the first 3 years after the papers were published, and $102(13 \%)$ papers were cited only once in the same period. Fifty-two percent of the total papers were singleauthor work and 2 authors published $18 \%$ of these. The most cited paper was published by 7 authors. Therefore documents with 7 authors had the highest CPP, followed by those with 9 and 6 authors. A detailed list of the distribution of publications and citations by number of authors per document are shown in Table 4, and it clearly indicates that independent authors and small groups were the most-often method of collaboration. Documents with 4 or fewer authors contributed $89 \%$ of the total production. This study shows a special result of the bibliometric analysis in information retrieval, as single-author papers were the most-popular type of authorship. In addition, the most frequently cited papers since publication to 2003 of each year in the time span of 1991 to 2003 were selected as shown in Table 5. Seven papers were listed due to an identical citation number, where half of them were published by the UK followed by Germany, the US, the Netherlands, and Canada. Countries' CPPs, from 1991 to 2001 
are listed in Table 6. The US has the highest CPP followed by Australia, and the Netherlands, making up the top 3 CPP ranking countries. Among all countries, the US, the UK, and Germany contributed the most not only in terms of publications but also in citations.

Table 6. Publication productivity of countries and their citation impact in three years after publication

\begin{tabular}{|c|c|c|c|}
\hline Country & $P$ & $\mathrm{C}$ & $\mathrm{CCP}$ \\
\hline UK & 155 & 466 & 3.01 \\
\hline Germany & 146 & 270 & 1.85 \\
\hline USA & 125 & $1710 *$ & $13.7 *$ \\
\hline France & 30 & 37 & 1.23 \\
\hline Switzerland & 25 & 14 & 0.560 \\
\hline India & 20 & 14 & 0.700 \\
\hline Netherlands & 19 & 110 & 5.79 \\
\hline Austria & 17 & 34 & 2.00 \\
\hline Canada & 16 & 29 & 1.81 \\
\hline Italy & 13 & 16 & 1.23 \\
\hline Australia & 8 & 58 & 7.25 \\
\hline Russia & 8 & 1 & 0.125 \\
\hline Israel & 6 & 15 & 2.50 \\
\hline Sweden & 6 & 12 & 2.00 \\
\hline Pakistan & 5 & 6 & 1.20 \\
\hline Belgium & 4 & 6 & 1.50 \\
\hline Ireland & 3 & 11 & 3.67 \\
\hline Norway & 3 & 9 & 3.00 \\
\hline Spain & 3 & 3 & 1.00 \\
\hline New Zealand & 3 & 1 & 0.333 \\
\hline Denmark & 2 & 9 & 4.50 \\
\hline Mexico & 2 & 5 & 2.50 \\
\hline Nepal & 1 & 4 & 4.00 \\
\hline Armenia & 1 & 1 & 1.00 \\
\hline Colombia & 1 & 1 & 1.00 \\
\hline Rep of Georgia & 1 & 1 & 1.00 \\
\hline Other 14 countries & 25 & 0 & 0 \\
\hline
\end{tabular}

*: Included the most cited paper which citation was total citation since it published to 2003 P: Total publications

$\mathrm{C}$ : Cited times for the first three years since it published

CPP: Citation per publication 
An analysis of the corresponding author, the institute, and the countries were undertaken for the publications from 1991 to 2001. 538 papers with records of corresponding author in the ISI were analyzed. $349(65 \%)$ authors published only 1 paper as corresponding author and $36(6.7 \%)$ authors published 2 papers. Table 7 shows the top 22 most-productive corresponding authors between 1991 and 2001.

Table 7. The 20 most productive corresponding authors between 1991 and 2001

\begin{tabular}{cllrrc}
\hline Ranking & Corresponding author & Country & P & C & CPP \\
\hline 1 & Ernst E & UK & 26 & 115 & 4.42 \\
2 & Walach H & Germany & 10 & 22 & 2.20 \\
3 & Loscher W & Germany & 7 & 11 & 1.57 \\
4 & Fisher P & UK & 6 & 24 & 4.00 \\
4 & Jacobs J & USA & 6 & 16 & 2.67 \\
4 & Linde K & Germany & 6 & 32 & 5.33 \\
7 & Reilly D & UK & 5 & 50 & 10.0 \\
7 & Vickers AJ & UK & 5 & 13 & 2.60 \\
9 & Dean ME & UK & 4 & 4 & 1.00 \\
9 & Gebhardt KH & Germany & 4 & 0 & 0 \\
9 & Harisch G & Germany & 4 & 4 & 1.00 \\
9 & Wiesenauer M & Germany & 4 & 4 & 1.00 \\
13 & Calabrese EJ & USA & 3 & 43 & 14.3 \\
13 & Diener HC & Germany & 3 & 10 & 3.33 \\
13 & Donner F & Germany & 3 & 0 & 0 \\
13 & Furnham A & UK & 3 & 0 & 0 \\
13 & Hochstrasser B & Switzerland & 3 & 0 & 0 \\
13 & Hunter FE & UK & 3 & 0 & 0 \\
13 & Jonas W & USA & 3 & 14 & 4.67 \\
13 & Jonas WB & USA & 3 & 7 & 2.33 \\
13 & Lewith G & UK & 3 & 4 & 1.33 \\
13 & Thomas KJ & UK & 3 & 52 & 17.3 \\
\hline
\end{tabular}

P: Total publications

$\mathrm{C}$ : Cited times for the first three years since it published

CPP: Citation per publication

Nine corresponding authors were from the UK, 8 from Germany, 4 from the US, and 1 from Switzerland. Ernst from the UK with 26 papers dominated publications as the corresponding author, followed distantly by Walach from Germany, who had 10 corresponding author papers. Among the top 20 most productive corresponding authors, Linde had the highest CPP value (5.33). Five hundred ninety three papers were recorded with 395 corresponding institutes and countries in the ISI. $316(53 \%)$ institutes published only 1 paper as corresponding institute, $41(6.9 \%)$ published 2 papers, and 48 (8.1\%) published 3 papers. Table 8 provides a list of the top 22 most-productive corresponding institutes between 1991 and 2001. Nine corresponding institutes were in Germany, 8 in the UK, 2 in the US, and 1 each in Austria, the Netherlands, and 
Switzerland. The University of Exeter in the UK had the highest frequency as corresponding institute, followed distantly by the Technische Universität München and the University of Freiburg in Germany. Among these top 22 most productive corresponding institutes, the University of Limburg in the Netherlands had the highest CPP value (11.3). Furthermore, 9 (25\%) countries published only 1 paper as corresponding country, 7 (19\%) published 2 papers, and 4 (11\%) published 3 papers.

Table 8. The 22 most productive corresponding institutes between 1991 and 2001

\begin{tabular}{cllrrc}
\hline Ranking Corresponding institute & Country & P & C & CPP \\
\hline 1 & Univ Exeter & UK & 31 & 148 & 4.77 \\
2 & Tech Univ Munich & Germany & 9 & 32 & 3.56 \\
2 & Univ Freiberg & Germany & 9 & 20 & 2.22 \\
4 & Tierarztliche Hsch Hannover & Germany & 8 & 6 & 0.750 \\
5 & Glasgow Homoeopath Hosp & UK & 7 & 37 & 5.29 \\
6 & Uniformed Serv Univ Hlth Sci & USA & 6 & 21 & 3.50 \\
6 & Univ Glasgow & UK & 6 & 21 & 3.50 \\
6 & Univ Birmingham & UK & 6 & 20 & 3.33 \\
6 & Univ Gottingen & Germany & 6 & 13 & 2.17 \\
6 & Univ York & UK & 6 & 10 & 1.67 \\
6 & Graz Univ & Austria & 6 & 9 & 1.50 \\
12 & Royal London Homoeopath Hosp & UK & 5 & 28 & 5.60 \\
12 & Res Council Complementary Med & UK & 5 & 14 & 2.80 \\
12 & Univ Heidelberg & Germany & 5 & 3 & 0.600 \\
15 & Univ Limburg & Netherlands & 4 & 45 & 11.3 \\
15 & Univ Massachusetts & USA & 4 & 43 & 10.8 \\
15 & Hannover Sch Vet Med & Germany & 4 & 9 & 2.25 \\
15 & Univ Hamburg & Germany & 4 & 3 & 0.750 \\
15 & Univ Bonn & Germany & 4 & 2 & 0.500 \\
15 & Univ Erlangen Nurnberg & Germany & 4 & 2 & 0.500 \\
15 & Univ Bern & Switzerland & 4 & 0 & 0 \\
15 & Univ London Univ Coll & UK & 4 & 0 & 0 \\
\hline & & & & & \\
\end{tabular}

P: Total publications

$\mathrm{C}$ : Cited times for the first three years since it published

CPP: Citation per publication

Table 9 shows the top 10 most productive corresponding countries between 1991 and 2001. Among these top 10 most productive corresponding countries, the US had the highest CPP value with the most frequently cited paper that was cited 1172 times since it was published to 2003. The corresponding author was located in the UK, Germany, and the US for more than half of the papers $(395,52 \%)$ considered. 
Table 9. The 10 most productive corresponding countries between 1991 and 2001

\begin{tabular}{lrrl}
\hline Corresponding country & P & C & CPP \\
\hline UK & 142 & 440 & 3.10 \\
Germany & 136 & 152 & 1.12 \\
USA & 117 & $506^{*}$ & $4.32^{*}$ \\
France & 30 & 37 & 1.23 \\
Switzerland & 23 & 13 & 0.565 \\
India & 19 & 14 & 0.737 \\
Netherlands & 18 & 107 & 5.94 \\
Canada & 16 & 29 & 1.81 \\
Austria & 14 & 23 & 1.64 \\
Italy & 13 & 16 & 1.23 \\
\hline
\end{tabular}

P: Total publications

C: Cited times for the first three years since it published CPP: Citation per publication

\section{Most frequently cited papers}

The time dependence on a single article is called its history and may be viewed as the 'sales figure' of the article (MARX \& CARDONA, 2003). Similarly, the time dependence for a topic, homeopathy research in this study, can also be called its history and can similarly be viewed as a sales figure of the research topic. Figure 3 shows the relationship between paper life and percentage of cited papers in a year. In the beginning year (zero year here), this was lower because all papers appeared in that the published year. The percentage of cited papers suddenly rise in the next two years and reached their maximum after two years, after which a decline was visible.

The citation history of the most frequently cited papers, such as reviews and editorials is shown in Figure 4. There was a peak a year after publication for both reviews and editorials. After that, a decline was visible. The peak position depended on the research discipline and shifted to about four years as the publication in the case of technical sciences (MESSINA et al., 1994). 


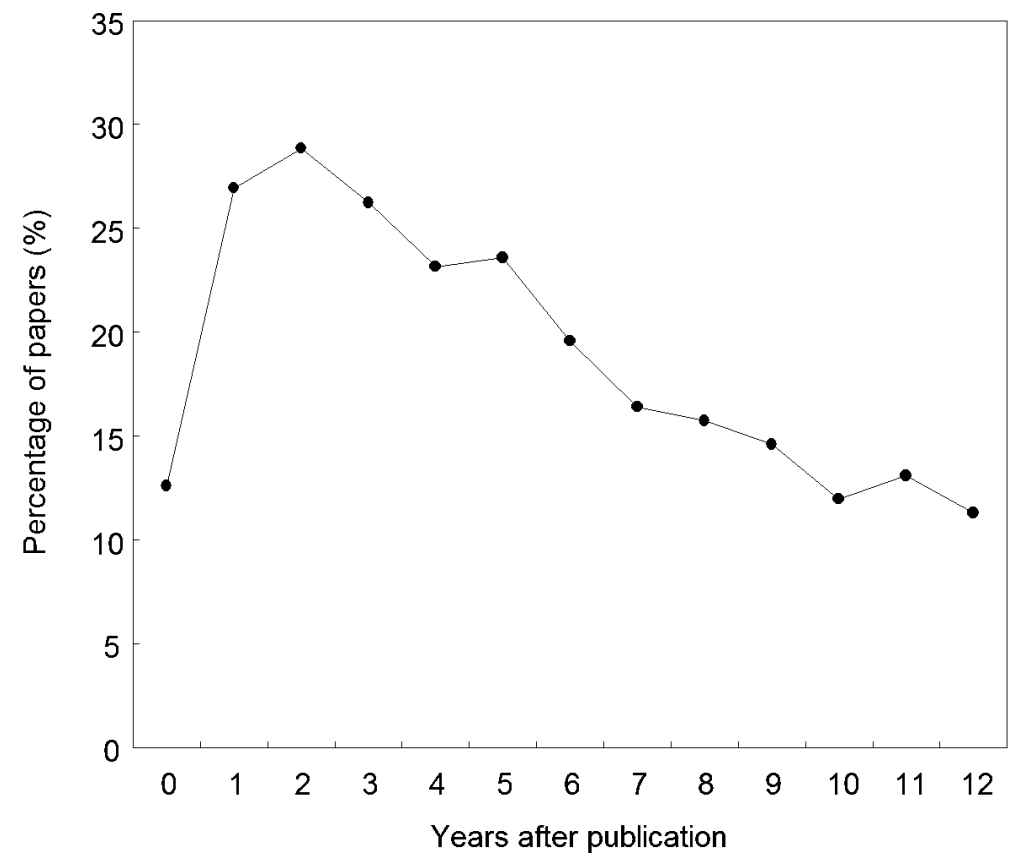

Figure 3. Citation history of homeopathy research

\section{Citation model}

For the period from 1991 to 1997, the cumulative number of citations increased. In the published year for all papers published in the period from 1991 to 1997, 58 citations were obtained, while 6 years after papers were published; the cumulative number of citations was 1850. A model can be used to describe the relationship between the cumulative number of citations, $C_{\mathrm{c}}$, and the paper life, $Y$.

There was a linear relationship with a high coefficient of determination (0.999). The model can be expressed as:

$$
C_{c}=K Y+S
$$

where $K$ is the citation rate (number of times cited/year), and $S$ is the visibility potential when a paper is published (number of times cited). Moreover, $S$ is a measure of how quickly the "average article" in the field is cited. The $S$ shows how often articles published in the field are cited within the same year. 


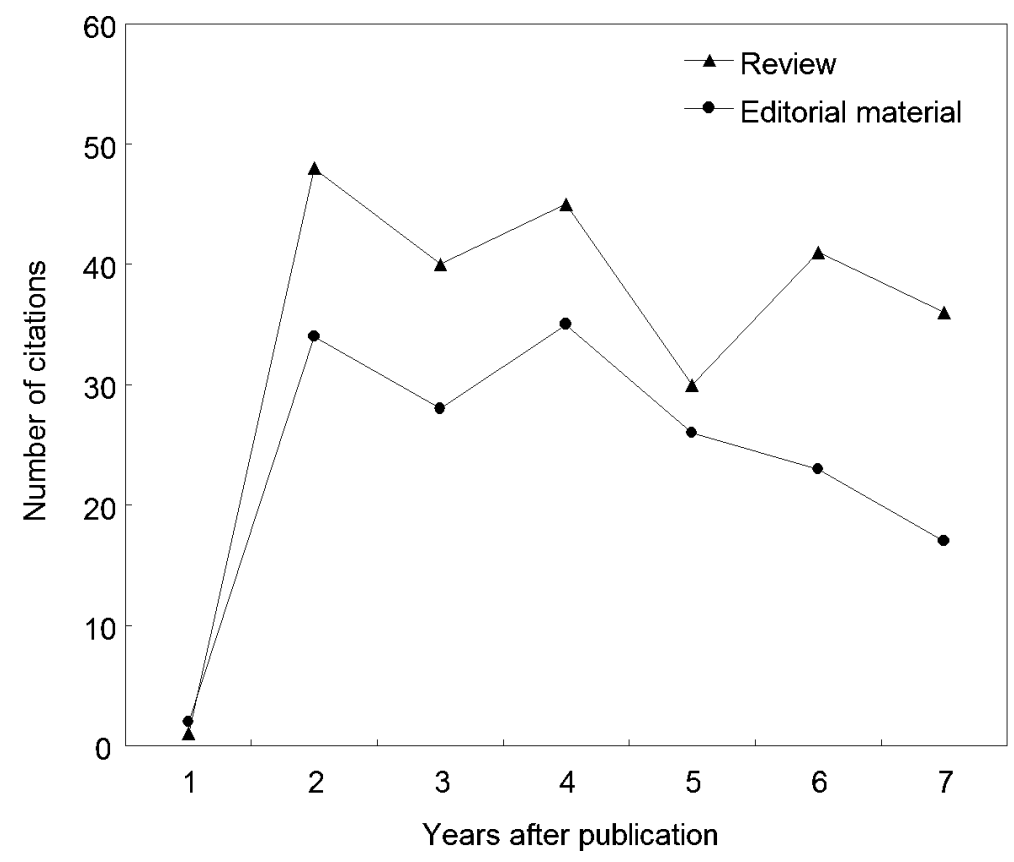

Figure 4. Citation history of the most frequently cited papers

The values of the constants $K$ and $S$ were found to be 303 times cited/year and 21.7 times cited, respectively; and so the model for homeopathy research papers published in 1991 to 1997 , can be written as:

$$
C_{c}=303 Y+21.7
$$

This model fitting suggested that there was sustained constant citations in each year. Figure 5 shows that significant correlations between the yearly cumulative number of citations in three years after publication and the paper life were made for the years from 1991 to 1997 with the model having high coefficients of determination (> 0.988). The results indicated that papers published in 1997, had the highest visibility potential followed by that in 1992. However papers published in 1991, had the highest citation rate. In other words, homeopathy research papers published in 1997 had the highest visibility potential and the greatest numbers of times cited each year after the papers were published. 


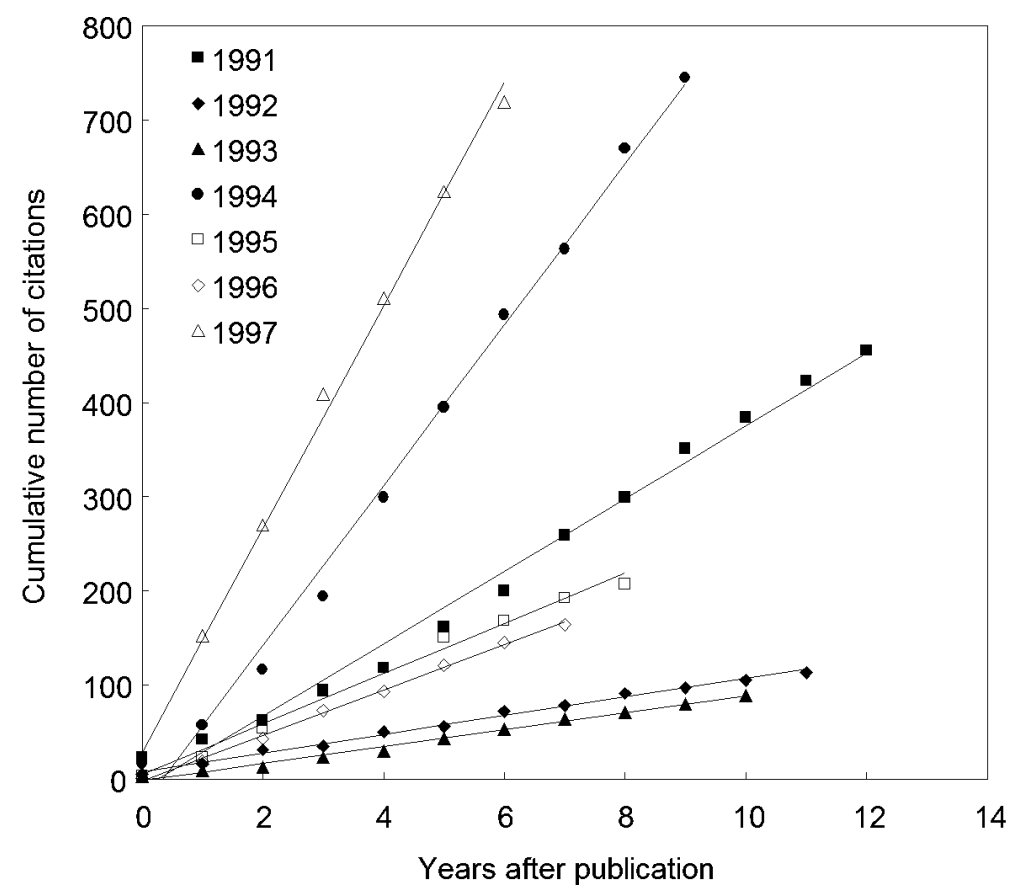

Figure 5. Relationships between the cumulative number of citations and age of papers with simulated models

\section{Conclusion}

Two linear relations between yearly cumulative number of publications and the year were obtained for the two periods from 1991 to 1997 and 1997 to 2003 in which there were 50 average annual publications for the early period and 100 for the latter period. More document types and languages, and fewer pages have appeared in homeopathy research compared with other research fields. English remains the dominant languages while German contributed a high number of publications. Small-group collaboration was a popular method of co-authorship. The top three ranking countries of publication were the UK, the US, and Germany. The US dominated citations followed by the UK and then Germany. The University of Exeter in the UK had the highest frequency as corresponding institute. The most frequently cited article was published in the JAMA-Journal of the American Medical Association which is the second highest impact factor journal in the category of General \& Internal Medicine. The 20 top cited papers were written by 70 authors from 5 different countries, were all published in English. 
Moreover, a linear model was successfully applied to describe the relationship between the cumulative number of citations in three years after publication and paper life.

\section{References}

Bordons, M., BArrigon, S., Mendez, A. (1996), Spanish investigation in international pharmacy and pharmacology journals from 1980-1989. Medicina Clinica, 106 : 51-59.

Burton GoldBerg Group (1993), Alternative Medicine, The Definitive Guide 1993, Future Medicine Publishing, Washington, USA.

Chiu, W. T., HuAng, J. S., Ho, Y. S. (2004), Bibliometric analysis of severe acute respiratory syndromerelated research in the beginning stage. Scientometrics, $61: 69-77$.

Eisenberg, D. M., Davis, R. B., EtTner, S. L., Appel, S., Wilkey, S., van Rompay, M., Kessler, R. C. (1998), Trends in alternative medicine use in the United States, 1990-1997 - Results of a follow-up national survey. JAMA-Journal of the American Medical Association, 280 : 1569-1575.

Evans, W. (2001), Mapping mainstream and fringe medicine on the Internet. Science Communication, $22: 292-299$.

Keating, J. C., Caldwell, S., Nguyen, H., SAljooghi, S., Smith, B. (1998), A descriptive analysis of the Journal of Manipulative and Physiological Therapeutics, 1989-1996. Journal of Manipulative and Physiological Therapeutics, 21 : 539-552.

LANCASTER, F. W., Zeter, M. J., MetZler, L. (1992), Ranganathan influence examined bibliometrically. Libri, 42 : 268-281.

MarX, W., CARDOnA, M. (2003), The impact of Solid State Communications in view of the ISI Citation data. Solid State Communications, 127 : 323-336.

Messina, M. J., Persky, V., Setchell, K. D. R., Barnes, S. (1994), Soy intake and cancer risk - A review of the in-vitro and in-vivo data. Nutrition and Cancer - An International Journal, 21 : 113-131.

Rivas, A. L., Wilson, D. J., Gonzalez, R. N., Mohammed, H. O., Quimby, F. W., Lein, D. H., Milligan, R. A., Colle, R. D., Deshler, J. D., Trochim, W. M. K. (1997), An interdisciplinary and systemsbased evaluation of academic programs: Bovine mastitis-related veterinary research, education and outreach. Scientometrics, $40: 195-213$.

Tutosaus, J. D., Oller, J. D., Blazquez, I. G., Conde, S. M., Mendez, S. M. (2001), International scientific production in digestive laparoscopic surgery. Revista Espanola de Enfermedades Digestivas, $93: 452-458$.

Ugolini, D., Mela, G. S. (2003), Oncological research overview in the European Union. A 5-year survey. European Journal of Cancer, 39 : 1888-1894.

WAKIJ, E. M. (1997), Mapping the literature of physical therapy. Bulletin of the Medical Library Association, $85: 284-288$.

ZHANG, H. Q. (1995), Basic literature of acupuncture in MEDLINE: A bibliometric analysis. Libri, $45: 113-122$.

Zhang, H. Q., He, D. G., HE, L., Li, J. (1997), The literature of Qigong: Publication patterns and subject headings. International Forum on Information and Documentation, 22 : 38-44. 


\section{Appendix A}

The 21 most frequently cited papers (citations in three years after publication) between 1991 and 2001

\begin{tabular}{|c|c|c|c|}
\hline Rank & $\mathrm{C}$ & DT & Article \\
\hline 1 & $1172 *$ & Article & $\begin{array}{l}\text { Eisenberg, D.M., Davis, R.B., Ettner, S.L., Appel, S., Wilkey, S., van Rompay, } \\
\text { M. and Kessler, R.C. (1998), Trends in alternative medicine use in the United } \\
\text { States, 1990-1997 - Results of a follow-up national survey. JAMA-Journal of the } \\
\text { American Medical Association, } 280 \text { (18), 1569-1575. }\end{array}$ \\
\hline 2 & 89 & Review & $\begin{array}{l}\text { Linde, K., Clausius, N., Ramirez, G., Melchart, D., Eitel, N., Hedges, L.V. and } \\
\text { Jonas, W.B. (1997), Are the clinical effects of homoeopathy placebo effects? A } \\
\text { meta-analysis of placebo-controlled trials? Lancet, } \mathbf{3 5 0}(9081), 834-843 \text {. }\end{array}$ \\
\hline 3 & 64 & $\begin{array}{l}\text { Editorial } \\
\text { Material }\end{array}$ & $\begin{array}{l}\text { Eisenberg, D.M. (1997), Advising patients who seek alternative medical } \\
\text { therapies. Annals of Internal Medicine, 127 (1), 61-69. }\end{array}$ \\
\hline 4 & 54 & Article & $\begin{array}{l}\text { Wetzel, M.S., Eisenberg, D.M. and Kaptchuk, T.J. (1998), Courses involving } \\
\text { complementary and alternative medicine at US medical schools. JAMA-Journal of } \\
\text { the American Medical Association, } 280 \text { (9), 784-787. }\end{array}$ \\
\hline 5 & 38 & Article & $\begin{array}{l}\text { Thomas, K.J., Nicholl, J.P. and Coleman, P. (2001), Use and expenditure on } \\
\text { complementary medicine in England: A population based survey. Complementary } \\
\text { Therapies in Medicine, } 9 \text { (1), 2-11. }\end{array}$ \\
\hline 6 & 32 & Article & $\begin{array}{l}\text { Taylor, M.A., Reilly, D., Llewellyn-Jones, R.H., McSharry, C. and Aitchison, } \\
\text { T.C. (2000), Randomised controlled trial of homoeopathy versus placebo in } \\
\text { perennial allergic rhinitis with overview of four trial series. British Medical } \\
\text { Journal, } 321 \text { (7259), 471-476. }\end{array}$ \\
\hline 6 & 32 & Review & $\begin{array}{l}\text { Kleijnen, J., Knipschild, P. and Terriet, G. (1991), Clinical-trials of homeopathy. } \\
\text { British Medical Journal, } 302 \text { (6772), 316-323. }\end{array}$ \\
\hline 8 & 30 & Article & $\begin{array}{l}\text { Ernst, E. and White, A. (2000), The BBC survey of complementary medicine use } \\
\text { in the UK. Complementary Therapies in Medicine, } 8 \text { (1), 32-36. }\end{array}$ \\
\hline 9 & 28 & $\begin{array}{l}\text { Editorial } \\
\text { Material }\end{array}$ & $\begin{array}{l}\text { Vandenbroucke, J.P. (1997), Homoeopathy trials: Going nowhere - Commentary. } \\
\text { Lancet, } 350 \text { (9081), } 824 .\end{array}$ \\
\hline 10 & 21 & Article & $\begin{array}{l}\text { Downer, S.M., Cody, M.M., Mccluskey, P., Wilson, P.D., Arnott, S.J., Lister, } \\
\text { T.A. and Slevin, M.L. (1994), Pursuit and practice of complementary therapies by } \\
\text { cancer-patients receiving conventional treatment. British Medical Journal, } \mathbf{3 0 9} \\
(6947), 86-89 .\end{array}$ \\
\hline 11 & 21 & Article & $\begin{array}{l}\text { Fisher, P. and Ward, A. (1994), Medicine in Europe. 8. Complementary medicine } \\
\text { in Europe. British Medical Journal, } 309 \text { (6947), 107-111. }\end{array}$ \\
\hline 12 & 19 & Review & $\begin{array}{l}\text { Astin, J.A., Marie, B., Pelletier, K.R., Hansen, E. and Haskell, W.L. (1998), A } \\
\text { review of the incorporation of complementary and alternative medicine by } \\
\text { mainstream physicians. Archives of Internal Medicine, } 158 \text { (21), 2303-2310. }\end{array}$ \\
\hline 13 & 17 & Review & $\begin{array}{l}\text { Ziment, I. and Tashkin, D.P. (2000), Alternative medicine for allergy and asthma. } \\
\text { Journal of Allergy and Clinical Immunology, } \mathbf{1 0 6} \text { (4), 603-614. }\end{array}$ \\
\hline
\end{tabular}




\begin{tabular}{|c|c|c|c|}
\hline Rank & $\mathrm{C}$ & DT & Article \\
\hline 14 & 16 & Article & $\begin{array}{l}\text { Linde, K., Scholz, M., Ramirez, G., Clausius, N., Melchart, D. and Jonas, W.B. } \\
\text { (1999), Impact of study quality on outcome in placebo-controlled trials of } \\
\text { homeopathy. Journal of Clinical Epidemiology, } 52 \text { (7), 631-636. }\end{array}$ \\
\hline 14 & 16 & Article & $\begin{array}{l}\text { Calabrese, E.J. and Baldwin, L.A. (1999), The marginalization of hormesis. } \\
\text { Toxicologic Pathology, } 27 \text { (2), 187-194. }\end{array}$ \\
\hline 15 & 15 & Article & $\begin{array}{l}\text { Walach, H., Haeusler, W., Lowes, T., Mussbach, D., Schamell, U., Springer, W., } \\
\text { Stritzel, G., Gaus, W. and Haag, G. (1997), Classical homeopathic treatment of } \\
\text { chronic headaches. Cephalalgia, } 17 \text { (2), 119-126. }\end{array}$ \\
\hline 15 & 15 & Article & $\begin{array}{l}\text { Calabrese, E.J. and Baldwin, L.A. (2000), The marginalization of hormesis. } \\
\text { Human \& Experimental Toxicology, } 19 \text { (1), 32-40. }\end{array}$ \\
\hline 17 & 14 & Article & $\begin{array}{l}\text { Jacobs, J., Jimenez, L.M., Gloyd, S.S., Gale, J.L. and Crothers, D. (1994), } \\
\text { Treatment of acute childhood diarrhea with homeopathic medicine: A randomized } \\
\text { clinical-trial in nicaragua. Pediatrics, } \mathbf{9 3} \text { (5), 719-725. }\end{array}$ \\
\hline 17 & 14 & Article & $\begin{array}{l}\text { Allaire, A.D., Moos, M.K. and Wells, S.R. (2000), Complementary and } \\
\text { alternative medicine in pregnancy: A survey of North Carolina certified nurse- } \\
\text { midwives. Obstetrics and Gynecology, } \mathbf{9 5}(1), 19-23 \text {. }\end{array}$ \\
\hline 17 & 14 & Article & $\begin{array}{l}\text { Whitmarsh, T.E., Coleston Shields, D.M. and Steiner, T.J. (1997), Double-blind } \\
\text { randomized placebo-controlled study of homoeopathic prophylaxis of migraine. } \\
\text { Cephalalgia, } 17 \text { (5), 600-604. }\end{array}$ \\
\hline 17 & 14 & Article & $\begin{array}{l}\text { Vandenbroucke, J.P. and de Craen, A.J.M. (2001), Alternative medicine: A } \\
\text { "mirror image" for scientific reasoning in conventional medicine. Annals of } \\
\text { Internal Medicine, } \mathbf{1 3 5} \text { (7), 507-513. }\end{array}$ \\
\hline
\end{tabular}

C: Cited times for the first three years since it published

Cited times since it published to 2003 